\title{
Sociologia dA CARNE ELETRónicA. Cultura DIGITAL E O IMAGINÁRIO DO OBSCENO
}

\author{
Vincenzo Susca
}

\begin{abstract}
RESUMO
Ao contrário da ênfase inicial que tem sido dado a aspetos relacionados com a inteligência e o conhecimento, conclui-se que a web está a transformar-se progressivamente numa plataforma que convida formas estéticas e éticas marcadas por sentidos, emoções e voluptuosidades do prazer, perspetivadas até a partir de um lado negro. Noutras épocas, a pornografia era escondida, obscurecida, pertencendo a uma dimensão marginal da vida coletiva. Hoje, a cultura digital favorece o advento da cultura porno, onde a pornografia assume uma matriz simbólica, um código comum, uma atmosfera. Neste contexto visual e sensitivo, o obsceno fica mais perto da verdade e a verdade apresenta-se como obscenidade. Que imaginário preside a esta constante mutação?
\end{abstract}

\section{PaLAVRAS-Chave}

Cultura digital; cultura porno; obsceno; imaginário

\begin{abstract}
Contrary to the initial emphasis that was given on aspects related to intelligence and knowledge, we are finding that the web is increasingly becoming a platform welcoming aesthetic and ethic forms marked by senses, emotions and voluptuousness in pleasure as much as in its darker side. Previously, pornography was a hidden, obscure and marginal dimension of collective life. Nowadays, digital culture favors the advent of porn culture, where porn tends to become a symbolic matrix, an ordinary code, an atmosphere. In this visual and sensitive context, the obscene gets closer to the truth and the truth appears as an obscene. What imaginary presides over this mutation at work?
\end{abstract}

\section{KeYwORDS}

Digital culture; imaginary; obscene; porn culture

O que fica depois da orgia? (Jean Baudrillard, 1990)

O que fica depois da orgia? Esta questão preocupou Jean Baudrillard durante algum tempo. Quando a escreveu, estava convencido de que a festa tinha terminado há muito. Terá sido esse o caso? A festa já teria terminado? Não estaremos a ser forçados a observar a realidade de um modo rígido, tradicional, ou existem agora outras formas, transfiguradas? Por exemplo, o que acontece quando o erotismo entra no quotidiano? O que acontece à imaginação noturna que invade a luz do dia e a festividade participa na rotina? 
Hoje, vemos certas comodidades impregnadas de perfumes afrodisíacos, romances em enormes cartazes publicitários, Viagra, cocaína, GHB e Red Bull, o regresso dos poppers e outros substitutos que constantemente estimulam a sensibilidade. Vivemos a saturação do cenário político, repleto de alusões sexuais, desempenhos obscenos, o sexting, dickpick, twerking, gastroporn, food porn (Coward, 1984) e outras práticas eróticas lascivas em torno da comida. Os tratamentos cosméticos aparecem para sublinhar cada curva do corpo.

O sistema de objetos, como um todo, tornou-se comum à medida que os designers começaram a dedicar-se à elaboração de artefactos de toda a espécie e forma, envolvendo um sex appeal que transmite a ideia de uma arte da sedução, após o envolvimento de padres, modelos, estrelas de rock, intelectuais e empresários em escândalos sexuais...

Vejamos ao nosso redor: as paredes que rodeavam a indústria pornográfica caíram. Os espaços anteriormente obscuros encontram agora outra luz e os elementos que faziam parte do porno mais hardcore proliferam em cada recanto do espaço público, apoiados em fenómenos de contágio viral.

Pela primeira vez desde os tempos primitivos do Éden, o sexo tem vindo a tornar-se numa atividade comum e publicamente visível. De certo modo e independentemente da nossa vontade, todos participamos na sexualidade (Ballard, 2014, p. 114).

\section{BEM-VINDOS À INDÚSTRIA PORNO}

A viver o seu auge, a sociedade do consumo (Baudrillard, 1970) proporciona uma estrutura pornográfica. Isto não é propriamente uma metáfora, mas uma conceção verdadeira sobre uma dinâmica fundamental, um fluxo vital, nem é tão obscura quanto se possa pensar. Este paradigma do consumo, inflamado por desejos sensitivos, baseia-se na excitação. Seduz o corpo, convidando-o à voluptuosidade, agitando tumultuosamente a carne até aos limites da sua intoxicação, onde, frequentemente, a fruição do prazer se confronta com a ansiedade intrigante da morte.

A delapidação de um objeto apresenta sempre a substituição de outro (Debord, 1992). Neste sentido, cada orgasmo que se procura no pornográfico é sempre o pretexto para encontrar outro clímax, mais audaz, formidável e excecional. Mesmo se não for real, pouco importa. A acrobática, que se perpetua no corpo orgástico - a performance porno - nos seus espasmos e mordidelas, refere-se sempre ao trilho que procura ultrapassar os seus limites. Envolve-se num fascínio intoxicante do espetáculo. Estes movimentos enredam-se igualmente num pânico de uma jornada em remoinho rumo ao precipício. Revelam-se depois do prazer, quando o êxtase festivo termina, a Terra volta ao chão, quando o cenário se torna num palco de ruínas...

A parábola do merchandise e do corpo erotizado, onde reside a sociedade do espetáculo, assume-se num lançamento épico em contínuo. Culmina na dissipação, numa promessa crescente de uma ansiedade que está por chegar. É um destapar gradual de uma situação, constantemente relacionado com reativação do desejo: uma estória destinada a exalar sexualidade e - não apenas - sublimar cada pedaço orgânico e inorgânico das nossas existências. Nesta estória, que oscila entre a obscenidade e um horror vacui, 
todos somos máscaras, palhaços e figuras grotescas que participam num carnaval que ultrapassa as suas fronteiras originais. Torna-se incontrolável pelos seus tumultos e variações, à frente ou atrás do palco público. Autonomiza-se do âmbito político, económico e mediático. Por isso, a trajetória do porno oferece uma metáfora instrutiva sobre as fundações da disseminação do erotismo pela vida quotidiana, bem como os seus efeitos mais perversos.

\section{DA PORNOGRAFIA À CULTURA PORNO}

Até há poucos anos, a pornografia lidava com um universo específico de um grupo de fãs com perfis socioculturais homogéneos (Adamo, 2004). Esta tribo era consistente e levava a cabo uma série de testes para, cuidadosamente, integrar apenas os que se enquadravam no perfil tipo deste público. Por isso, apenas se admitiam os indivíduos que assumiam um comportamento conduzido pelo desejo erótico, mais intenso do que qualquer barreira de timidez, capazes de cumprir um salto transgressivo no abismo do prazer. Como, por exemplo, assistir a um filme para maiores de 18, comprar uma cassete de vídeo ou DVD, ou atravessar o hall de uma sala escura, onde os rituais iniciais do instinto pornográfico se desenrolam, praticada essencialmente por homens pouco preocupados com as rotinas habituais ou o comportamento socialmente clássico.

Nos últimos anos, testemunhámos o desenvolvimento de novas tecnologias de comunicação (primeiro a web 2.o, depois a geolocalização), em sintonia com a emergência de desejos e dissolução de inibições que marcaram a História desde os anos 1960 até ao presente. Tais ferramentas levaram à criação de uma nova economia sexual (Combessie, 2013), como símbolo de uma transformação profunda deste fenómeno, expandindo-o de forma exorbitante. A pornografia emancipou-se de um certo papel marginal que lhe era conferido, nos média e na cultura contemporânea. Neste sentido, plataformas como Youporn, PornTub, RedTube, PornHub, XHamster, Xvideos.com, entre outras, têm vindo a sinalizar insistentemente as relações entre a sexualidade e as redes. Entraram no Olimpo da sociabilidade eletrónica.

Através dos ecrãs, compreendemos as formas tangíveis de uma conexão tensa, própria do fluxo da cultura digital (Susca, 2016), que adquire um valor proeminente através da confusão carnal que promove. Estas potencialidades oferecem a possibilidade de o corpo transcender a singularidade individual, a sua identidade e autenticidade. Imersas em fluxos líquidos, o erotismo ferve. Estes fluxos de elevada densidade emocional são os locais de encontro da dissolução da humanidade e conjugam inesperadas situações com o "outro": o sexual, inorgânico, místico, o "outro" cultural... De facto, os ecrãs escaldantes dos sites pornográficos não estão limitados pelo corpo, nem pelo convite carnal. Não são apenas uma membrana que oferece um conjunto de ligamentos de gaze táctil. Acima de tudo, representam laboratórios para a desconstrução e regeneração do corpo - desde a carne física à carne eletrónica - como se fossem dispositivos simbólicos e um órgão sexual.

Num vídeo pornográfico, cada close-up é um ato onde o corpo é desintegrado. Decompõe-se a si próprio, em pedaços, enquanto as fronteiras somáticas e os limites 
simbólicos do corpo estão a ser testados, experimentando picos de prazer. Como se as estruturas de cada cena pornográfica fossem as torres de controlo das análises que são feitas sobre esse produto. Onde as fronteiras da humanidade, o seu divertimento e fruição estão em permanente teste e manipulação.

As imagens velozes que se exibem, inundadas por aspetos mecânicos com um ritmo encantador e frenético, a expansão de todas as cavidades do corpo e a sua obstrução, denotam uma certa tortura perturbadora. O sexo, como os orifícios orgânicos e inorgânicos, bem como os outros aparelhos do prazer, atua como um agente de passagem que converge no "outro" numa interseção de poros capaz de engoli-lo. Estes planos da imagem tornam o ser num agente múltiplo, como diriam Gilles Deleuze e Felix Guattari (1980), uma marca cada vez mais presente na sociedade contemporânea.

Toda a logística representada com o nanny porn, os fetiches, MILF, GILF, as fantasias, o Interracial, as Beurettes, o BDSM, Shemale, os brinquedos e monstros... transforma-se em categorias integrantes do mundo dos sites porno, batizadas por uma atmosfera caracterizada pelos princípios do prazer, alteração e violência. São simultaneamente laboratórios e matadouros de carne fresca, em plena renovação e substituição, virada do avesso e colada às peças. A vida que está por vir é cortada e cosida aos poucos. É também aqui que os corpos são renovados e sacrificados, tal como aprendemos através da sabedoria carnavalesca: as culturas são exuberantes e celebrantes, criadas e arquivadas.

$\mathrm{O}$ aspeto mais importante dos arquétipos disseminados no porno digital, para além do seu caráter de novidade, situa-se no seu timbre heterodoxo. Desafia os padrões de identificação sexual consolidados: favorece conjunções sem precedentes, de vestuário combinado ou estranho, ligações aos limites do ser humano, capazes de arrasar com a ordem monolítica e dicotómica do paradigma da nossa tradição cultural: "como se a citação exacerbada de Garden of Delights, de Hieronymus Bosch, estivesse a borbulhar nos interstícios das redes, e a imaginação canalizada para os territórios do humano-animal-máquina se misturassem entre si" (Ciuffoli, 2006, p. 116).

A pornografia que existe na web é, portanto, muito mais do que o júbilo da luxúria da carne. Prefere representar o agenciamento da disrupção até à sua dissipação definitiva: o matadouro do humanismo, uma poesia apocalíptica. O prazer pode ser interpretado como o anoitecer do acesso (Nancy, 2001). Isso significa o tom de uma transição, a excitação de quem vê um vídeo sexual e coloca o corpo em efervescência. Prepara-se um estado de transe prodigiosa, uma jornada longe do egoísmo. Envolve a visão de um qualquer lugar onde o sentido e a imaginação estão em sintonia: corpos e quilobytes, sonho e informação, pesadelo e comunicação...

A pornografia assume-se, por conseguinte, numa diáspora, uma navegação tumultuosa da carne.

A luxúria é a questão central do Desconhecido, tal como a Cerebralidade é uma questão espiritual.

A luxúria é o gesto criado e em criação.

A luxúria é uma eterna batalha perdida. Depois do triunfo do combaten-

te, o efémero triunfa por si próprio, ressurgindo uma insatisfação que 
empurra, numa vontade orgiástica, o ser, que floresce e se supera.

A luxúria é o prazer. (Valentine of Saint-Point, 1913).

\section{A CARNE TORNA-SE NO LOGOS}

Para compreender adequadamente a natureza constante da mutação antropológica - objeto e tema da nossa pesquisa - é necessário analisar as distintas características da paisagem porno, entre padrões básicos e traços identitários atuais. Por um lado, existem as redes sociais pornográficas e eróticas, como o Youporn.com, que é um dos mais extraordinários exemplos. Por outro, devemos considerar as diversas atualizações que emergem deste caso e que atuam como colmeias orientadas por sistemas telemáticos de geolocalização, de gostos, perfis e desejos.

Registada em dezembro de 2005, por uma empresa da Califórnia, o site Youporn teve de um sucesso de tal forma repentino que, ao lado de muitos outros do mesmo género, entrou pouco tempo depois na lista das 50 páginas mais visitadas na Internet, em todo o mundo. Pela sua singularidade, num estilo simples e cativante, transpunha a lógica do Youtube para o universo porno, possibilitando que os utilizadores produzissem e avaliassem conteúdos na plataforma. Esta operação acabaria por ser financiada através da publicidade para outras páginas, como linhas telefónicas eróticas ou grupos de chat privados em que se proporcionava um espaço para encontros - diretos e indiretos - a todos aqueles que partilhavam um interesse comum pelos prazeres, tendências e estilos desta área.

Diariamente, o arquipélago da pornografia enriquece-se com milhares de novos vídeos, capazes de atrair um número exorbitante de visitas em poucas horas depois da sua disponibilização online. Cada uma dessas "ilhas" oferece uma perspetiva fragmentada da realidade - um sintoma da tribalização que se vive num mundo pós-moderno (Maffesoli, 1988) - que coloca em relação a sociedade com os seus gostos. Os visitantes deste site, e os incontáveis concorrentes do mesmo, lutam através de diferentes espaços desta "paisagem", de acordo com as preferências de cada um. Assim, determinam opções variadas, que correspondem a diversas identidades e mapas do imaginário porno e erótico, mas não só...

Estes dados expressivos indicam claramente que o porno se tornou claramente num produto mainstream. Já não está confinado à marginalidade subcultural onde esteve durante muito tempo até à explosão da web 2.0. O público que o segue é, em teoria, toda a massa de utilizadores da web. A pornografia desempenha um papel de liderança neste ambiente comunicativo, como indicam diversas estatísticas: a palavra "sexo" é a mais procurada nos motores de busca, 35\% dos downloads globais têm conteúdo obsceno e $12 \%$ dos sites são de cariz sexual (Wired, 2014). Por isso, o porno é um dos principais agitadores da cultura da internet e, consequentemente, um milieu cultural e contemporâneo consistente.

Já não parece ser relevante tratar esta tendência como se fosse um fenómeno de nicho ou um género específico. A web 2.o e os seus seguidores promoveram a emancipação 
da cultura porno. Esta sensibilidade apropria-se da rede digital e contamina o advento da cultura porno. A "red line" liga o porno à cultura popular (Regazzoni, 2010). Os vídeos do Youporn, o canal online Jacquie and Michel e o site Zombi porn estão todos instrumentalizados para provocar imagens que posteriormente são utilizadas pela indústria da publicidade, seduzindo inúmeros passageiros no metropolitano (Abruzzese, 2010). As sex shop, entre as mais ousadas e as mais soft, as mais populares e luxuriosas, estão em constante ligação com os ecrãs dos smartphones. Os romances eróticos, mais ou menos triviais, parecem-se a episódios nebulosos que envolvem líderes políticos da atualidade: o caso "Bunga Bunga", com Silvio Berlusconi, o escândalo sexual de Dominique Strauss-Kahn, bem como as estórias que mancharam as carreiras de Bettino Craxi, Bill Clinton, Nicolas Sarkozy ou François Hollande...

Os políticos, por exemplo, utilizam uma certa hierodulia que confirma uma supremacia sagrada, responsável por assegurar o monopólio da obscenidade e transgressão, em segredo e com distanciamento em relação a todas bases de poder e idades (Girard, 1985). O espetáculo (pseudo)orgiástico inconscientemente proporcionado por estes representantes de classe desencadeia, por um lado, a harmonização do poder instituído através da utilização do erotismo societal. O objetivo, por um lado, reside na restauração da correspondência perdida entre aqueles que governam e aqueles que vivem. Por outro, estes representantes atuam como musas excecionais do corpo social, operando com distanciamento do olhar comum. A experimentação da performance, a exasperação de tons e a constância de humores supõem a devolução da supremacia dos políticos no espaço público. Em contrapartida, o público entende este comportamento dos políticos como algo habitual e sem consequências importantes no futuro. Será apenas um simulacro, porque o espaço público, sobretudo no domínio da esfera digital, derrubou as barreiras que separam o episódio em concreto do teatro da obscenidade.

Neste sentido, pouco importa as formas concretas destes fenómenos, apenas a nossa imersão na realidade pornográfica e cultural. As redes que dela emergem são a causa, o efeito e ambiente sonoro que se dissemina de forma viral. Na verdade, o ambiente mediático em que estamos envolvidos depende muito dos paradigmas que contagiam os média eletrónicos, epidérmicos e tácteis (McLuhan 1962/1977, 1962/2004). Os média não são apenas ferramentas de comunicação e meios de informação, mas a pele da cultura (De Kerckhove, 1998, 2014). Como pele da cultura, a base semântica dos média eletrónicos é o lugar por excelência da contaminação dos corpos. Estes caracterizam a obscenidade contemporânea, apresentam e dissolvem a sensibilidade do nosso tempo, que entra num carga somática, com fantasias e fluídos corporais.

Deste modo, as redes porno eróticas constituem-se em múltiplos espaços num só: um paroxismo prodigioso, uma alegoria orgiástica e confusa entre a carne e os quilobytes na Internet, numa figura exacerbada, que não será a primeira, nem a última, a experimentar uma dança extasiante que agita a sociabilidade contemporânea.

Ao contrário do que sucedia anteriormente, as interações e combinações deste contexto febril já não são orientadas por estruturas simples do pornográfico. A dimensão da narrativa desempenha um papel marginal nestas práticas, que florescem em zonas erógenas da web. Invadem os ecrãs com cenas repetitivas, curtas, improvisadas - quase em 
obsessão - inspirando as categorias pelas quais se organizam. Esta narrativa aparece decorada com muitos close up redundantes e explícitos. O que é consumido aqui, como corolário da escrita em colapso, torna-se numa saturação da gaze. Por outras palavras, o que está em jogo é a exuberância de uma experiência que claramente ultrapassa as fronteiras do tangível. A produção e a visão em raio-X já não se dirigem aos olhos, mas são antes induzidas e empurradas pelo corpo, que vê apenas o que se estende e toca apenas onde é tocado.

O processo de escrita de determinadas partes do vídeo pornográfico emana da decomposição gramatical do corpo, que se representa pelo seu excesso: em magreza, com uma sensação de prurido, húmido, sangrando, com sujidade, escondido, dilatado, ferido... Nesta perspetiva, de acordo com Massimo Canevacci, a Internet erótica "confirma a transição da pornografia tradicional para a versão mais crua do porno: a narrativa desaparece e o porno torna-se exclusivamente visual"'. A paisagem visual e a paisagem porno estão relacionadas, onde se questiona a racionalidade dominante em termos da sua ordem alfabética e a sobreposição da sua base divina. Ambas confrontam o equilíbrio entre o sagrado e o profano, instituído desde a atribuição das Tábuas da Lei a Moisés. "E nela existia o trabalho de Deus, e a sua escrita foi obra de Deus, gravada nestas tábuas" (Antigo Testamento, Êxodo 32).

A paisagem cultural que surge nos espaços viscosos da web transforma-se perentoriamente neste equilíbrio entre o Logos e a carne, em que se baseia a cultura Ocidental desde o Antigo Testamento: "no princípio era o Verbo, e o Verbo estava com Deus, e o Verbo era Deus. (...) Nele estava a vida, e a vida era a luz dos homens. E o Verbo se fez carne, e habitou entre nós" (João, 1-4).

A aura de sacrilégio do porno (especialmente no universo pagão e na versão selvagem proporcionada pela web 2.0), de corpos em ebulição, confere substância à sensibilidade onde, ao contrário do que assiste atualmente, "a carne transformou-se em Logos".

A carne torna-se no significado principal do imaginário contemporâneo.

A liturgia orgiástica que ali surge é uma espécie de ritual de sacrifício rodeado de lacerações, um totem e fetiche. É o lugar onde o culto do corpo e da mística com traços dionisíacos é celebrado e ritualizado, onde o carácter sagrado e o erótico estão amarrados no mais profundo e íntimo abraço.

\section{Afinidades eróticas}

Os prazeres que podem ser encontrados nas salas de chat, nos ecrãs e nas janelas da cultura porno, acrescentam um outro toque à civilização moderna e ocidental. Muda o seu núcleo - a criação e a procriação - para a recreação generalizada, independente da produção e distanciada da lógica do progresso. O porno é a metáfora sumptuosa do consumo mais improdutivo que existe. Apoiando-se numa disseminação capilar, pelas mais variadas camadas da sociedade, insinua-se constantemente em diversos interstícios da sociedade. Torna-se um estilo de vida mobilizado pelo apetite sexual, em

\footnotetext{
' Esta frase foi retirada das correspondências entre M. Canevacci e o autor deste texto.
} 
detrimento da vida laboral, um comportamento lascivo que substitui as fronteiras da burguesia. Subtrai-se a si próprio do dever em nome de um hedonismo sem escrúpulos, longe da moralidade, transformando-se na nova norma.

De um modo sintomático, a galáxia simbólica do cinema pornográfico, assente num terreno fértil, inspira-se no quotidiano, em todos os enredos que nele se podem encontrar: a decoração, mas também os realizadores e os utilizadores-protagonistas. Refere-se a uma existência perfeitamente normal. Expressa uma visão do mundo, a partir de baixo e em direção a um lugar específico (Bakhtine, 1998), como se define nos termos clássicos.

É o caso de Gonzo e Indie, mas especialmente de Realcore (Messina, 2010). É um género recente na pornografia, que se caracteriza por sistemas técnicos e estéticos, bastante libidinoso, do mundo subterrâneo, quase grotesco.

A qualidade deste tipo de produções aproxima-se de um diletantismo rude, que não requer qualquer ficção ou transfiguração. Os filmes que se extraem das plataformas anteriormente mencionadas apresentam consecutivamente cenas em cascata. Apresentam-se desde contextos domésticos ou lugares inusitados, em detrimentos dos tradicionais set dos filmes. Entre os filmes que se encontram no mercado, podemos distinguir entre conteúdos de natureza espontânea ou em simulacro. Os amadores, que criam os cenários de qualidade, lidam com outros profissionais que pretendem ser amadores, para atrair espectadores em busca de uma autenticidade tão real quanto possível. $\mathrm{O}$ conteúdo primário da Web 2.0 estabelece-se, efetivamente, numa rede de utilizadores, em plena informação, de carne e símbolos que lhe estão associados.

Neste sentido, e em perfeita sintonia com o mundo dos média, a pornografia 2.0 mostra o quotidiano, ainda que possa revelar alguns simulacros. $O$ espetáculo é organizado e interpretado pelo ritmo do dia a dia. Neste tipo específico de conteúdos, os planos do ordinário e extraordinário intersetam-se, gerando curto-circuitos e virtuosidades.

Os protagonistas fazem parte de um universo comum, desempenhando papéis de doméstica, precários, bloggers, estudantes, em apartamentos onde a roupa aparece espalhada, ou utilizando peças de vestuário desenhadas pelos próprios intervenientes. Misturam-se com performances de excelente qualidade, em espaços desorganizados, ocupados com gemidos como os de Vaudeville, em atos extraordinariamente prolongados, com práticas extremas, captadas a partir de câmaras colocadas em diversos ângulos. A banalidade transforma-se no fantástico, conferindo um valor substancial à estética vulgar, que irradia do corpo social.

$\mathrm{Na}$ maior parte dos casos, o consumo e a visualização do porno eletrónico decorre precisamente nos momentos mais aborrecidos do quotidiano dos utilizadores, em detrimento das áreas obscuras e espaços fechados, em autonomia própria, à margem do tempo livre. Esta prática transgressiva preenche assim um espaço vazio, que depois atinge o seu corolário com a manifestação de um sentimento de culpa por parte de quem assiste. O porno já deixou de ser um ultraje, tornando-se numa aspiração para contrariar e provocar o status quo de uma sociedade. É visto com euforia, se não de forma hilariante, em leveza, homenageando os cultos hedonistas.

A pornografia é do senso comum e está presente em todos os sentidos. 


\section{AS LINHAS do DESEJo, AS Linhas PARA O DESEJO}

Redes wireless, memórias e telefones sem fio, e outras nuvens de armazenamento de dados nos computadores, constroem a territorialidade física do simbólico, do emocional e dos frames sonhados, alterando as modalidades comunicativas do inabitável (Di Felice, 2010) para a geografia do prazer, numa experiência vivida. É igualmente inquestionável que estas modalidades superam o domínio da sensibilidade e sensualidade. Somos desafiados a interpretar a implementação das técnicas geolocalizadas, através de aplicações como o Tinder ou Happn, que permitem a realização de encontros eróticos adequados a determinados gostos, afinidades e estilos, mas também a disposições, tamanhos e fetiches.

Hoje, mais do que nunca, e mais do que seria expectável por parte dos indivíduos, este sistema reticular da comunicação permite uma abrangência de movimentos entre fluxos metropolitanos (La Rocca, 2013). Os indivíduos são hoje pós-urbanos, inundados de desejos afetivos e sexuais que precisam de ser realizados imediatamente, através da conjugação entre informação e corpo, fantasias e encontros, visões e experiência.

Estes software e apps promovem o agendamento em tempo real, para os seus utilizadores, do mapa, da disponibilidade e dos perfis de outras pessoas que se enquadram num interesse mútuo, tendo em vista a concretização de um encontro a breve prazo. Esta perspetiva leva a que o ambiente sensitivo se sobreponha ao imaginário, ao erotismo e ao plano físico. Ficamos imersos numa paisagem de total integração, onde o visível, os desejos, afetos e sentidos se tornam, como definiram alguns surrealistas, um território material (Alquié, 1955; Breton, 1962/2005). O que acontece aqui encontra muitas semelhanças com o que acontecia nos anos 1980, com as revistas, que, oferecendo óculos 3D, prometiam aos leitores que conseguiriam ver através da roupa, cumprindo assim a sua promessa publicitária.

Hoje em dia, a sede, o capricho e as fantasias dos que se encontram geograficamente próximos a nós - ou que o podem estar, depois de uma troca rápida de mensagens - têm vindo a converter-se numa transparência evidente, ainda que despidos. É o caso de sistemas que se organizam por opacidades, ligações e iniciações ao culto neotribal. Por isso é que dois passageiros no metro não são mais do que indivíduos anónimos que partilham um espaço, num dado tempo específico. São também parceiros virtuais do erótico - no mais interessante e preciso termo, "que existe em poder", com tendência para se atualizar a si próprio (Levy, 1996). A proxémica torna-se ciência, uma experiência consciente e impregnada de erotismo. Ao mesmo tempo, as relações que se baseiam no "estar junto" florescem essencialmente como ligações densas de erotismo.

As afinidades que se ligam são, igualmente, mobilizadas imediata ou primariamente pelo erotismo. A cidade inteligente configura-se, acima de tudo, num espaço erógeno e erótico: inteligente, precisamente. Movida e agitada pela carne. Ficamos sujeitos a imprevisíveis e incontroláveis desejos que alteram os nossos movimentos urbanos, redirecionando-nos para redes adulteradas. Como somos sujeitos que aspiram a um desejo, mas acima de tudo vivemos desse sentimento, tornamo-nos desejo de outros, ainda que muitos deles possam ser estranhos, passantes ou softwares intolerantes. 


\section{IMAGINÁRIO SENSUAL}

É muito curioso observar a similitude da imersão na paisagem porno com o consumo de narcóticos como a cocaína (Bagozzi \& Cippitelli, 2008), sobretudo a que se verifica entre as ghoo e as 17 hoo (Wired, 2014). Esta coincidência distorce o tempo supostamente dedicado ao período laboral. Aqui se fixam os vestígios das substâncias tradicionalmente noturnas, normalmente provenientes da imaginação coletiva.

A invasão da noite em plena luz do dia decorre de uma alteração da harmonia Apoliana. Pelas dissonâncias, desgostos e distorções, uma sombra espalha-se e ameaça o coração do sistema social. Um espectro destaca-se pelo mundo: o sensual espectro da cultura porno.

Estes tumultos provocam desordem dentro do sistema político, cultural e produtivo. Em proporcionalidade direta com a materialização crescente, torna-se o palco principal da cultura. Escapa-se assim dos subúrbios onde viveu clandestinamente durante anos, num fantasma que nasce do subterrâneo. Como forma cada vez menos etérea e mais tangível, é parte do modelo capitalista de desenvolvimento, uma indústria cultural e, de forma mais genérica, uma estrutura do mundo moderno. Ainda assim, o porno, no seu modo mais irredutível de ameaça à lógica da produção económica e da representação social, configura-se numa célula lunática. Com um efeito perverso. Um cancro.

O porno surge, de repente, como um modelo económico. Mas o imaginário que deriva do porno coloca em causa a ordem estabelecida. Carrega valores, ética e estética que são imediatamente ameaças por ele. Em vez de tentativas astutas orquestradas pelas ideologias neoliberais, que subjugam a sua violência e caráter dissimulador e selvagem, levando por vezes a um ato exutório, a cultura porno ainda apresenta uma qualidade irrefutável. Como força ingovernável, no fundo é um sistema improdutivo. Claramente dedicado ao desperdício, fatalmente destinado à luxúria, devota de um espírito dionisíaco, com os seus mais atuais avatares.

Para ilustrar o que tem sido referido anteriormente, deve considerar-se de que formas estas insinuações entram em contacto com o mundo profissional da atualidade. Essas circunstâncias transformam o trabalhador num ator-porno, utilizador-porno e um produtor-porno. Todos espreitam nos ecrãs dos computadores, movendo-se compulsivamente de uma janela para a outra, entre um relatório que precisa de ser preparado e uma conversação com um(a) colega no Skype. Este espírito está alojado entre a consulta das notícias e da previsão do tempo, entre hashtags da moda e emoji ridículos. Esta imagem provocativa contraria o zelo das tarefas e as responsabilidades que uma profissão sugere, convidando os funcionários, entre os mais criativos e os freelancer, a acompanhar, com um simples clique, uma onda de prazer, dentro do espaço-tempo do trabalho.

A atenção é imediatamente lançada através de um impulso sexual, a partir de um dispositivo com múltiplas imagens. É um fragmento que transmite impulsos, que desconstrói e contamina o mosaico das tarefas, as funções profissionais e a leitura de política e economia. O prazer porno erótico não convida somente à distração, mas também à masturbação. Devemos não esquecer que é necessária uma abstração para não nos distrairmos do plano material! Esta atividade, ainda que intelectual, distrai o corpo do 
trabalho, pelo desgaste em tempo de lazer. É uma bomba prestes a rebentar, pela sua deriva perigosa e pelos seus efeitos explosivos que gravitam em torno dela. Estar demasiado próximo desta trajetória implica necessariamente a contaminação de uma presença insidiosa, invasiva, corrupta.

O desenvolvimento deste ambiente traz repercussões cruciais para o conteúdo pornográfico, uma vez que precisa de ser calibrado pela fluidez e aceleração das comunicações eletrónicas (Di Marino, 2013). Isto explica a curta duração dos vídeos porno. Oferecem instantaneamente ao espectador o que ele pretende, a substância que ele deseja. Esta última geração de paisagens porno eletrónicas - mesmo quando recicladas para outros sites ou filmes - exibe vídeos de curta e média duração. Não incluem os habituais intervalos ou cenas transitórias como as que eram exibidas na pornografia clássica (Baudry, 2016; Servois, 2009).

Podemos argumentar que, de uma forma ou outra, estes fragmentos de imagens e narrativas configuram formas culturais que se intersetam com o resto dos média mainstream e a vida quotidiana. Publicidade, design, política e televisão, desde La Ferme aux Célébrités à serie Master of sex, True blood (Attimonelli, 2012), de Californication (Pireddu, 2015) a outros média, constituem as premissas da continuidade do que há mais puro e genuíno no universo porno. Em todo o caso, não existem mais barreiras, mas porosidades e afinidades recíprocas entre o porno e o resto do sistema comunicativo.

A natureza multitasking da cultura digital significa que simultaneamente, através de diversos média, podemos levar a cabo diferentes tarefas. Enquanto escrevemos, podemos estar a ouvir a última música de Jamie $x x$, ao mesmo tempo que identificamos alguém num álbum fotográfico da última festa a que fomos, reservamos a próxima viagem transalpina e participamos em conversas de um grupo de investigação.

Este ambiente incentiva a que prestemos apenas atenção parcial às atividades que desenvolvemos, na medida em que todas elas se encontram direta ou indiretamente relacionadas.

Um site leva a outro, uma informação sugere que o utilizador consulte outra fonte de uma notícia, um tweet conjuga uma série de vozes, e um post que raramente é consultado resulta em múltiplas conversações. Pode acontecer que uma imagem interessante de um banner desperte uma pesquisa no Google sobre a fórmula tecnomágica do termo "porno", proporcionando um destino inevitável da navegação eletrónica. Andar de um lado para o outro na Internet resulta a que, muito facilmente, se não de modo automático, coloquemos os nossos instintos mais básicos em erupção. É aqui que as visões mais maravilhosas ocorrem, em divagações inesperadas de uma carne que se encontra num trânsito insaciável.

O século XIX caracterizava-se pela aura voyeur que vagueava pelas ruas das cidades, entre prostitutas que se exibiam em janelas de lojas. Hoje, o corpo virtual passeia-se errantemente pelo fascínio da carne digital, a que está irremediavelmente preso (Abruzzese, 2010, p. 207). A internet surge como uma mescla provocativa de veias infernais, iconológicas e sonoras. Transmite uma imagem de espetáculo, de gordura efervescente, de corpos exorbitantes, excitando novas sátiras, e ninfas que exibem uma maquilhagem 
buxom, além de figuras transgénero. Celebra-se a conquista do prazer frequente, que coincide com a expressão mais crua do Homem. Utilizando uma visão estética pouco convencional e uma linguagem num estilo calão, sujo e deselegante, este lado provocativo não tem muitas semelhanças com os atos indecentes que se verificavam no movimento artístico avant-garde do século XX (Abruzzese, 2010; De Micheli, 2005), exibindo uma maior sensibilidade aos estímulos. Existe, portanto, uma renúncia a estruturas abstratas e conceptuais.

Neste contexto, os fornecedores da cultura pornográfica (Youporn, Xporn, Pornotube, Shufuni, Youjizz...) não são apenas pletóricos no arquipélago da web. Entram nas mais variadas narrativas online, em espaços urbanos e mediáticos, cujas narrativas são, com maior ou menor intensidade, marcadas por fortes conotações sexuais e teasers. Estas dinâmicas de mercado levam a que decorra uma espiral de excessos, de sons e imagens. São estes os agentes responsáveis pela preciosa mercadoria da economia contemporânea: uma atenção sensível (Gorz, 2003), empatia, um recurso escasso, a excitação dos utilizadores.

Este palco mediático aparece preenchido por uma multidão ruidosa com antigos e novos elementos pornográficos: políticos e spin doctors, publicitários, criativos e demiurgos do storytelling (Salmon, 2008). Todos eles são capazes de inflamar um determinado objeto, corpo ou experiência através de uma narrativa entusiasmante. São os pós-jornalistas da web 2.0, que não são mais do que os utilizadores das redes sociais prontas a consumir qualquer objeto, corpo ou experiência, que possa sublimar a deriva cenográfica mais mórbida. Finalmente, existem os terroristas do Estado Islâmico, que exploram os dispositivos espetaculares da nossa cultura (De Sutter, 2016), através do inconsciente e da cumplicidade negligenciada pelos média e pelos cibernautas ocidentais, na medida em que são impostos determinados discursos de uma ordem e da economia aparatosa da catástrofe ${ }^{2}$.

Neste sentido, não deveremos ignorar a recente mediatização excessiva, na televisão, mas também nas redes sociais (sobretudo no Facebook e no Twitter), de imagens macabras, de corpos desmembrados, engolidos e profanados, relativamente aos acontecimentos da noite de 14 de julho de 2016 em Nice, na "Promenade des Anglais", um atentado reivindicado pelo ISIS. Este episódio foi tudo menos uma representação, mas antes uma hiper-apresentação. Desenrolou-se longe do nosso discurso, uma mise-en-scene obscena de corpos dispostos no seu lado mais obscuro, atingindo uma dimensão sinistra, sensível à cultura porno que envolve a nossa época.

Através do uso e abuso do corpo dos outros, consumido pela fúria homicida de Mohamed Lahouaiej Bouhlel, esta mise-en-scene transfigura-se num material mediático. Demonstra a emergência de uma relação que poucos conheciam até àquele momento: um modo privado de distância e abstração. Fica marcada uma certa empatia, confundida com um outro sentido tão humano como a compaixão e a emoção, um pós-humano,

\footnotetext{
${ }^{2}$ Sobre esta relação entre os média, a catástrofe e o imaginário da cultura contemporânea, recomenda-se a consulta da tese de doutoramento de Bertrand Vidal, intitulada Les représentations collectives de l'événement-catastrophe : étude sociologique sur les peurs contemporaines, realizada na Universidade Paul-Valéry, em Montpellier, em 2012.
} 
que persiste na reificação, associando a vida humana a outros aspetos do mundo.

\section{A VIDA QUOTIDIANA, O OBSCENO F A VERDADE}

Talvez a definição de obscenidade possa tornar-se real, como elemento verdadeiro de algo que foi metaforizado ou com uma dimensão metafórica. A sexualidade, bem como a sedução, teve sempre uma dimensão metafórica. $\mathrm{Na}$ obscenidade, os corpos, órgãos sexuais e o ato sexual são brutalmente "encenados" e imediatamente dados a conhecer, para serem devorados. São absorvidos e reabsorvidos no mesmo palco. É uma representação total das coisas que são habituais no contexto da dramaturgia, uma cena, um jogo entre competidores. Não existe jogo, nem dialeto nem vazio, mas uma autêntica colisão de elementos. (Baudrillard, 2000).

O sistema comunicativo assenta no entendimento, de acordo com os pioneiros do pensamento nesta área, na garantia do triunfo da ciência Ocidental e da consciência (Lévy, 1994). De qualquer modo, o lado obscuro da humanidade, aquele que apresenta até um lado amaldiçoado, prolifera e expande os seus tentáculos. Este é um dos paradoxos mais significativos da nossa era. O ciberespaço e as derivações societais e técnicas tornam exagerado o prazer sensual, inflamando-o, tendo em conta que o ambiente central da cultura moderna tem simultaneamente estigmatizado e domesticado a vida, o poder e o conhecimento. Este processo microfísico, como diria Foucault (1979/2004), é invisível para todos os que procuram mudanças sociais, revoluções impressivas, no quadro genérico da cultura.

A rede mobiliza e continua a refletir a sua abrangência de múltiplas sensibilidades e inúmeros imaginários, que foram relegados para a margem da História (Susca, 2016). O corpo-a-corpo aparece generalizado, o sexo e a violência combatem freneticamente, juntos na iconologia do esperma, das secreções vaginais e no sangue que brota.

As flagrantes metáforas da liquidificação do humanismo constituem o dealbar da reforma e a decadência progressiva do Ocidente. Daí que se organizem prontamente todos estes sarcasmos que visam o bom gosto, os rituais de orgia, os deboches e a sociabilidade eletrónica (Casalegno, 2007). A efervescência festiva entra em contacto com danças macabras e com a dimensão carnavalesca da vida coletiva, representando e aumentando experiências que veem já desde a Idade Média.

A cultura porno que emerge de todo este ambiente encontra espaço amplo nos meandros do corpo social, entrando na veia das sociedades contemporâneas. Modifica as formas, transtorna a alma, a ética e as políticas, a estética e a economia. Na verdade, os média eletrónicos têm desempenhado um papel primordial da difusão do erotismo, um fenómeno recorrente desde os finais dos anos 1960 (Debord, 1988, 1992). Multiplicando a erotização, contaminando diversas redes em tempo real e em larga escala: entre um download e uma partilha, entre o sexting e a tentativa de marcação de encontros online. Os conteúdos já não são os mesmos, nem os produtores e as linguagens. $O$ 
ambiente alterou-se, outrora imunizado a estes apelos sexuais, distante do mundo da luxúria, da moda e das mercadorias.

Neste sentido, o porno não é apenas uma das estruturas que produz conteúdos para o consumo das massas que visa o entretenimento, como se sugeriu anteriormente. É um paradigma existencial do nosso quotidiano: um estilo de vida forjado em chamas de prazer. O corpo é dividido entre hedonismo e crueldade, mostra atrocidades e ritos orgiásticos, estilhaça a arte e a carne. O corpo é ainda habitado pelos seus excessos, através de uma contínua experimentação do prazer, que despe e incendeia a carne. Satisfaz o objeto e dissipa-o; condensa emoções noturnas, que estão reprimidas pelos comportamentos sociais e politicamente corretos.

Não é por acaso que o retrato integral e permanente do porno-erotismo - um significado subjetivo e objetivo - conduz a uma certa repulsa. Avança ao ritmo de contínuas e irritantes provocações. Repulsa atrás de repulsa, choque atrás de choque, fecha-se a cortina depois de revelado o seu conteúdo mais negro, o mais escandaloso para nós, filhos da modernidade e do humanismo.

A obscenidade é verdadeira e a verdade é obscena.

\section{REFERÊNCIAS BIBLIOGRÁFICAS}

Abruzzese, A. (2010). Youporn ou le capitalisme de la chair. Les Cahiers Européens de L'Imaginaire, 2.

Adamo, P. (2004). Il porno di massa. Percorsi dell'hard contemporaneo. Milão: Raffaello Cortina.

Alquié, F. (1955). Philosophie du surréalisme. Paris: Flammarion.

Attimonelli, A. (2012). "You are mine": True blood, ou mon cœur est mis à nu. Les Cahiers Européens de L'imaginaire, 4

Bagozzi, F. \& Cippitelli C. (2008). In estrema sostanza. Scenari, servizi e interventi sul consumo di cocaina. Rome: lacobelli.

Baudrillard, J. (1970). La société de consommation. Paris: Denoël.

Baudrillard, J. (2000). L'obscène, in mots de passe. Paris: Le Livre de poche.

Baudry, P. (2016). L'addiction à l'image pornographique. Paris: Éditions du Manuscrit.

Bakhtine, M. (1965/1998). L'œuvre de François Rabelais et la culture populaire au Moyen-Âge et sous la Renaissance. Paris: Gallimard.

Breton, A. (1962/2005). Manifeste du surréalisme. Paris: Folio essais.

Casalegno, F. (2007). Le cybersocialità. Nuovi media e nuove estetiche comunitarie. Milan: Il Saggiatore.

Ciuffoli, E. (2006). XXX. Corpo, porno, web. Roma: Castelvecchi.

Coward, R. (1984). Female desire: Women's sexuality today. Londres: Paladin Books.

De Kerckhove, D. (1994). Les nerfs de la culture: L'être humain à l'heure des machines à penser. Laval: Presses Université Laval. 
De Kerckhove, D. (2014). The point of being. In D. De Kerckhove \& C. Miranda (Eds.), The Point of Being. New Castle Upon Tyne: Cambridge Scholars Publishing.

De Micheli, M. (2005). Le avanguardie artistiche del Novecento. Milão: Feltrinelli.

De Sutter, L. (2016). Esthétique du trottoir. Les Cahiers Européens de L'Imaginaire, 8.

Debord, G. (1988). Commentaires sur la société du spectacle. Paris: Éditions Gérard Lebovici.

Debord, G. (1992). La société du spectacle. Paris: Gallimard.

Deleuze, G. \& Guattari, F. (1980). Capitalisme et schizophrénie 2: Mille plateaux. Paris: Les Éditions de Minuit.

Di Felice, M. (2010). Paesaggi post-urbani. La fine dell'esperienza urbana e le forme comunicative dell'abitare. Milão: Bevivino.

Di Marino, B. (2013). Hard media. La pornografia nelle arti visive, nel cinema e nel web. Milão: Johan \& Levi Editore.

Foucault, M. (1979/2004). Naissance de la biopolitique. Cours au Collège de France 1978-1979. Paris: Gallimard.

Girard, R. (1985). La violence et le sacré. Paris: Grasset.

Gorz, A. (2003). L'immatériel. Connaissance, valeur et capital. Paris: Galilée.

La Rocca, F. (2013). La ville dans tous ses états. Paris: CNRS éditions.

Lévy, P. (1994). L'intelligence collective. Pour une anthropologie du cyberspace. Paris: La Découverte.

Lévy, P. (1996). Qu'est-ce que le virtuel? Paris: La Découverte.

Maffesoli, M. (1988). Le temps des tribus. Le déclin de l'individualisme dans les sociétés de masse. Paris: Méridiens-Klincksieck.

McLuhan, H. M. (1962/1977). Galaxie Gutemberg. La genèse de l'homme typographique. Paris: Gallimard.

McLuhan, H. M. (1962/2004). Pour comprendre les médias. Paris: Seuil.

Messina, S. (2010). Real sex. Il porno alternativo è il nuovo rock'n' roll. Milão: Tunué.

Nancy, J-L. (2001). L' il y a du rapport sexuel. Paris: Galilée.

De Saint-Point, V. (1913/2005). Manifeste futuriste de la luxure, in Manifeste de la femme futuriste. Paris: Mille et une nuits.

Pireddu, M. (2015). Entre manque et désir. Culture de masse, consommation et communication dans Californication. Sociétés, 128(2), 61-73.

Regazzoni, V. (2010). Pornosofia. Filosofia del pop porno. Florença: Ponte alle Grazie.

Salmon, C. (2007). Storytelling. La machine à fabriquer des histoires et à formater les esprits. Paris: La Découverte.

Servois, J. (2009). Le cinéma pornographique. Paris: Vrin.

Susca, V. (2016). Les affinités connectives. Sociologie de la culture numérique. Paris: Cerf. 
Vidal B. (2012). Les représentations collectives de l'événement-catastrophe : étude sociologique sur les peurs contemporaines. Tese de Doutoramento, Universidade Paul-Valéry, Montpellier, França.

Wired Porno (2014). Inchiesta big data, 65.

\section{NOTA BIOGRÁFICA}

Vincenzo Susca é doutor em Sociologia, Maître de Conférences na Universidade Paul-Valéry em Montpellier, investigador do CEAQ (Sorbonne), editor da revista Cahiers Européens de l'imaginaire e McLuhan Fellow na Universidade de Toronto. Entre outras obras, publicou os livros Pornoculture (Milão, 2016, Montreal, 2017, Porto Alegre 2017, com Claudia Attimonelli); Les Affinités connectives (Paris, 2016); Gioia Tragica (Paris, 2011, Milão, 2016, Barcelona, 2012); Ai confine dell'immaginario (Milão, 2006, Porto Alegre, 2007); A l'ombre de Berlusconi (Milão, 2004, Paris, 2006).

E-mail: vincenzo.susca@univ-montp3.fr

Universidade Paul-Valery, 34 Route de Mende, 34090 Montpellier, França

* Submetido: 15/03/2017

*Aceite: 10/05/2017 